\title{
Evaluating the Genotoxic and Proximate Analysis of Ethanolic Extract of Lecaniodiscus
}

\section{cupanioides Planch. ex Benth.}

\author{
Oloyede, A. $\mathbf{M}^{1 *}$., Ottu, B ${ }^{1}$, Ogunsanwo, $K^{1}$, Bolarinwa, $K^{2}$ and Makinde, $K^{1}$ \\ ${ }^{1}$ Department of Cell Biology and Genetics, University of Lagos, Akoka, Lagos-Nigeria \\ ${ }^{2}$ Distance Learning Institute (DLI), University of Lagos, Akoka, Lagos, Nigeria
}

\section{*Correspondence to: \\ Oloyede, A.M \\ oloism@yahoo.com}

Received: 3 June 2020

Accepted: 28 June 2020

ePublished: : 20 October 2020

Keywords: Genotoxicity; Proximate analysis; heavy metals; L. cupanioides

\section{Abstract}

Lecaniodiscus cupanioides has been playing vital roles in traditional therapies in Nigeria towards management of several ailments such as malaria and breast tumour. In the quest to investigating its genotoxicity, 30 mice weighing between $20-25 \mathrm{~g}$ were placed in three groups of 10 mice each. Groups A and B, orally administered 100 and $400 \mathrm{mg}$ kg-1 of the extract respectively for 49 days, group $C$ received distilled water as control. At expiration of treatment the mice were sacrificed via jugular puncture. Femurs were disaticulated to extract marrow in bone for genotoxic assay. Heavy metal and proximate analysis was investigated using Atomic Absorption Spectrophotometry. Bone marrow analysis revealed increased number of MN PCEs dose-dependently in treatments compared to control. A significant decrease in the number of Bud PCE was observed between treatment and control. Insignificant $(p>0.05)$ dose-dependent increase in MN NCE and significant $(p<0.05)$ dose related increase was observed in $100 \mathrm{mg} \mathrm{kg-1}$ treatment, also extract did not affect ratio of PCE /PCE +NCE. In proximate evaluatio, carbohydrate was highest, followed by crude fiber, protein and ash respectively. From heavy metals evaluation, $\mathrm{Zn}$ was the highest, all metals observed were within permissible level. The insignificant result of PCE/ $\mathrm{PCE}+\mathrm{NCE}$ or MNE PCEs against control may infer that the extract is not aneugenic, clastogenic, cytotoxic or genotoxic to the bone marrow. Availability of $\mathrm{Cu}, \mathrm{Cr}, \mathrm{Mn}, \mathrm{Ni}$, and $\mathrm{Cd}$ at permissible level suggest the plant possess some health potentials. The extract can be affirmed to be devoid of genotoxicity within period, doses and battery of exposure.

\section{Citation:}

Oloyede AM, Ottu B, Ogunsanwo K, Bolarinwa K, Makinde K. Evaluating the Genotoxic and Proximate Analysis of Ethanolic Extract of Lecaniodiscus cupanioides Planch. ex Benth. Plant Biotechnology Persa 2020; 2(2): 14-20.

\section{Introduction}

Medicinal plants have been utilized for numerous therapeutic purposes consequent upon abundant secondary metabolites bioavailability such as alkaloids, phenols and flavonoids. These therapeutic interest is tremendous such that about $85 \%$ of primary health medication are derived from natural resource globally [1]. Medicinal plants are lead sources for drug synthesis [2]. Lecaniodiscus cupanioides Planch, belonging to sapindaceae family, is a short tropical tree of about 6-12m high, commonly found in Asia and Africa. It is known as aaka or akika, okpu, kafi-nama-zaki and utantan in Yoruba, Igbo, Hausa and Edo respectively [3, 4]. It has been pharmacologically reported to be effective against myriads of health maladies such as measles, fever, some liver diseases and wounds [5]. In southwestern Nigeria it is claimed to manage epilepsy and promote erection [4]. It also possess analgesic activities [6]. To our knowledge, this is the first study to determine the invivo genotoxic or nongenotoxic effect of l. cupanioides in mice with the aim of establishing its safety. Thus, this study investigated its genotoxicity on Swiss mice.

\section{Materials and Methods}

\section{Plant collection}

Lecanodiscus cupaniodes leaves were sourced in December 2018 in Oyo state, Nigeria. The plant was authenticated at the forest research institute of Nigeria (FRIN), Ibadan courtesy $\mathrm{Mr}$ Odewo S.A. Voucher specimen was prepared and deposited with identification FHI111668 at the Herbarium of the Forestry Research Institute of Nigeria (FRIN).

Copyright (C) 2020 The Author(s). This is an open-access article distributed under the terms of the Creative Commons Attribution License (http://creativecommons.org/licenses/by/4.0), which permits unrestricted use, distribution, and reproduction in any medium, provided the original work is properly cited. 


\section{Plant Extraction}

Freshly collected or harvested leaves were cleaned, washed, shredded and air dried at $40^{\circ} \mathrm{C}$ for 21 days. It was pulverized into powdery texture. Powdered leave $(1039 \mathrm{~g})$ sample was weighed and soaked in $2700 \mathrm{mls}$ ethanol for 48 hours. Extract was filtered and filtrate was evaporated into paste using regulated hotplate at $40 \pm 1^{\circ} \mathrm{C}$. The concentration was collected into a suitable container.

\section{Experimental Animal}

Thirty Mus musculus (Mice) weighing 20-25g were procured from BioVaccine Centre, NAFDAC, Yaba, Lagos. The animals were grouped into three cages of 10 mice each, and kept in animal house in zoological garden of the University of Lagos to acclimatize for 7 days. They were adequately supplied water and feeds ad-libitum. After acclimatization, groups; A and B were orally administered 100 and $400 \mathrm{mg} \mathrm{kg}-1$ of the extract respectively, while group $\mathrm{C}$ received distilled water. Treatment was administered daily for 49 days after which the mice were sacrificed via jugular puncture. The femur were harvested for bone marrow assays.

\section{Micronucleus Assay}

This assay was executed according to Alimba and Bakare [7]. The bone marrow cells from femur of mice were flushed with the FBS and centrifuged at 2000rpm 5minutes, the supernatant was removed. FBS was added and centrifuged again and supernatant was discarded. A drop of the cell suspension was placed onto a slide and using a pusher slide, a smear was created. The slides were air dried and fixed in methanol for 10 minutes. The fixed slides were stained with $0.25 \%$ May-Grunwald stain and then rinsed after 15 minutes with deionized water. After rinsing, it was stained using with Geimsa. The stained slides allowed to air dry for a day and then covered. The ratio of polychromatic erythrocytes (PCE) to normochromatic erythrocytes (NCE) was calculated based on the slides scored. Minimum of 1000 cells per mouse were examined for micronuclei in polychromatic erythrocytes (MnPCE). The differential staining of PCEs (bluish-purple), normochromatic erythrocytes (NCEs), pinkish-orange) and the relative size of the erythrocytes were indices for differentiating them. Nuclear abnormalities (NA) were also scored as cytotoxic parameters. Cells with two nuclei were considered as binucleated (BN), Notched nucleus (NT) contains vacuoles and appreciable depth into the nucleus that does not contain nuclear materials and budding nucleus (NBud). Decrease in PCE: NCE ratio was considered an indicator of bone marrow toxicity in- duced by mutagens.

\section{Determination of Heavy Metal}

The atomic absorption spectrophotometer (AAS) was used to estimate the following metals: $\mathrm{Mn}, \mathrm{Zn}, \mathrm{Cd}, \mathrm{Cu}, \mathrm{Cd}, \mathrm{Ni}$, and Cr. As described by Ayaz et al. [8]. $2 \mathrm{~g}$ of sample was placed in a crucible and subjected to heating at $550^{\circ} \mathrm{C}$ in a muffle furnace for $6 \mathrm{~h}$. The resultant ash was then placed in $5 \mathrm{ml}$ of concentrated nitric acid for digestion. It was then evaporated using hot plate. Small amount of distilled water was added to the digested residue, filtered and volume was made to $30 \mathrm{ml}$ using distilled water. Atomic absorption spectrophotometer was then utilized in quantitative analysis of the solutions produced.

\section{Determination of moisture content}

Moisture content was estimated according to AOAC [9]. $5 \mathrm{~g}$ of the dried extract of L. cupanioides was subjected to 105 oC heating in a hot air oven for $2 \mathrm{~h}$, dish was made to cool in desiccator, weighed and the moisture content evaluated by the following formula.

\section{Moisture $(\%)=($ Weight of sample - Dry weight $)$}

Weight of the sample taken

\section{Proximate analyses}

This analysis was executed according to AOAC [9]. The Parameters investigated for included ash, protein, fat, and crude fiber. All of these were carried out using the methods described by AOAC (9).

\section{Statistics}

Statistical analyses were performed using Microsoft Excel. Data expressed in format of Mean \pm SEM. The data was subjected to sample T-test, evaluating the statistical significance of the difference between two means of various parameters between the control and experimental group. The $\mathrm{P}$ value was found by means of Microsoft Excel.

\section{Determination of $\mathrm{pH}$}

The $\mathrm{pH}$ influences the taste and stability of oral gels. The Table 4: Proximate analysis of L. cupanioides

\section{Results}

Table1. Polychromatic erythrocytes (PCE) observed in bone marrow of mice administered with ethanolic L. cupanioides for 49 days.

\begin{tabular}{cccccc}
\hline \multirow{2}{*}{ Treatment } & MnPCE & NT PCE & Normal PCE & BN PCE & BUD \\
\hline Control & $314.13 \pm 3.05$ & $68 \pm 2.52$ & $208.13 \pm 4.62$ & $41 \pm 1.05$ & $75.5 \pm 3.61$ \\
$100 \mathrm{mg} / \mathrm{kg}$ & $351 \pm 10.41 \mathrm{~b}$ & $66.20 \pm 6.67$ & $206.25 \pm 3.67$ & $40 \pm 5.70$ & $50.8 \pm 9.12 \mathrm{a}$ \\
$400 \mathrm{mg} / \mathrm{kg}$ & $321.5 \pm 4.09$ & $59.50 \pm 3.57$ & $215.75 \pm 13.14$ & $55 \pm 3.54 \mathrm{c}$ & $56.25 \pm 8.09 \mathrm{a}$
\end{tabular}


Table 1 shows dose dependent-increase in the number of MN PCEs in the low and high concentration. No statistical significant treatment related increase of MN PCEs in the low and high concentration respectively. There was also a significant decrease in the number of Bud PCE observed in the low and high concentration.

Table 2: Normochromatic erythrocytes (NCE) observed in bone marrow of mice administered with ethanolic Lecaniodiscus cupanioides for 49 days

\begin{tabular}{cccc}
\hline Treatment & MnNCE & Normal NCE & NT NCE \\
\hline Control & $87.25 \pm 7.8$ & $171.25 \pm 8.02$ & $34.75 \pm 4.27$ \\
$100 \mathrm{mg} / \mathrm{kg}$ & $95.80 \pm 4.96$ & $136.80 \pm 14.34 \mathrm{a}$ & $53.40 \pm 1.58 \mathrm{a}$ \\
$400 \mathrm{mg} / \mathrm{kg}$ & $86 \pm 7.85$ & $174 \pm 6.77$ & $32 \pm 4.04$
\end{tabular}

Data represented as Mean $\pm \mathrm{SEM}, \mathrm{N}=10$

$(\mathrm{a}=\mathrm{P}<0.05, \mathrm{~b}=\mathrm{P}<0.01, \mathrm{c}=\mathrm{P}<0.001)$

Table 2, shows a dose related increase in the frequency of MN NCEs and significant treatment-related decrease in the number of NCEs observed in the low concentration.

Table 3: PCE/ (PCE+NCE) ratio in bone marrow

\begin{tabular}{cccc}
\hline Treatment & PCE & NCE & PCE/ (PCE + NCE) \\
\hline Control & $392.63 \pm 4.72$ & $293.25 \pm 3.14$ & $0.57 \pm 0.006$ \\
$100 \mathrm{mg} / \mathrm{kg}$ & $363 \pm 17.5$ & $286 \pm 9.57$ & $0.56 \pm 0.02$ \\
$400 \mathrm{mg} / \mathrm{kg}$ & $386.5 \pm 14.92$ & $292 \pm 15.20$ & $0.59 \pm 0.034$
\end{tabular}

Data represented as Mean $\pm \mathrm{SEM}, \mathrm{N}=10$

$(\mathrm{a}=\mathrm{P}<0.05, \mathrm{~b}=\mathrm{P}<0.01, \mathrm{c}=\mathrm{P}<0.001)$

No significant difference in PCE/ (PCE+NCE) ratio representing the absence of bone marrow cytotoxicity was observed in the mice after exposure to ethanolic extract of Lecaniodiscus cupanioides when compared with the control. The extract did not affect the frequency of the PCE/ (PCE+NCE) ratio, an indicator of toxicity to the bone marrow cells.
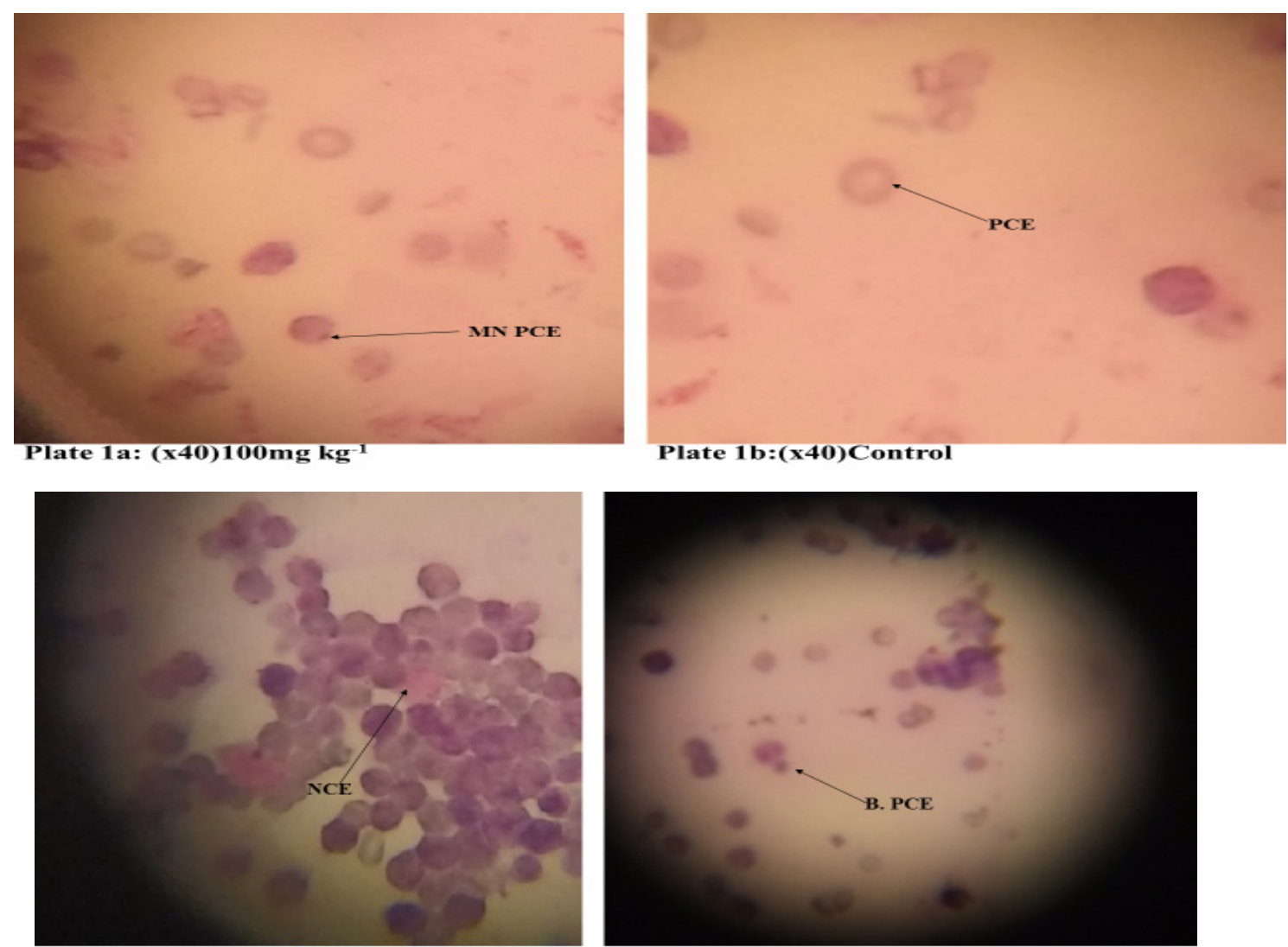

Plate 1c: (X40) Control

Plate 1d:(X40) $400 \mathrm{mg} \mathrm{kg}^{-1}$

16 | Plant Biotechnology Persa Volume 2, Issue 2, 2020 


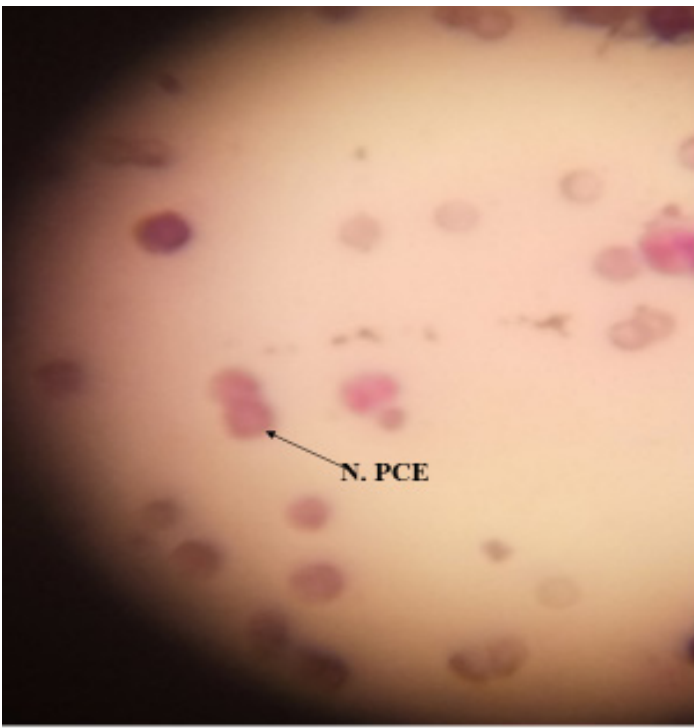

Plate 1e: $(\mathrm{X40}) 100 \mathrm{mg} \mathrm{kg}^{-1}$



Plate1g:(X40) 100mg

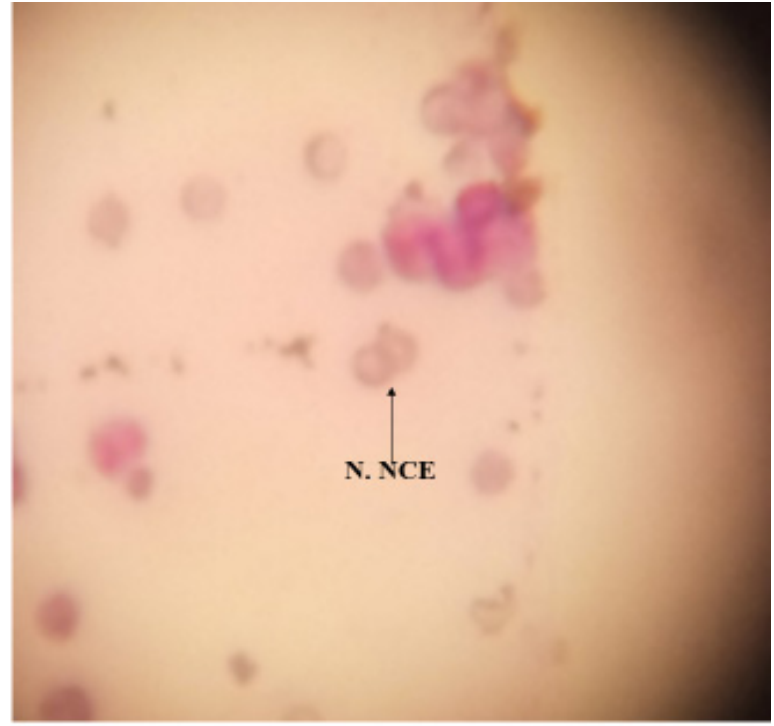

Plate 1f: (X40)Control

Plates 1A-G: showing various erythrocyte abnormalities. A; MN.PCE- micronucleated polychromatic erythrocytes (immature RBC possessing RNA and micronucleus). B; PCEpolychromatic erythrocytes (immature RBC containing RNA which matures into nomochromatic erythrocytes lacking RNA). C; NCE- Normochromatic erythrocytes (mature RBC that lacks RNA). Other nuclear abnormalities observed include binucleated, bud and notched cells. D; B.PCE- binucleated PCE (cells with two nuclei). D; Notched PCE, contains vacuole and an appreciable depth into the nucleus without nuclear materials. F; Notched NCE, contains vacuole and an appreciable depth into the nucleus without nuclear materials. G; Bd. PCE- Bud PCE (Nucleus appears to be budding out of the cell).

\begin{tabular}{cc}
\hline Parameter & Level Detected \\
\hline Moisture & $0.88 \%$ \\
Ash content & $8.21 \%$ \\
Fat content & $0.56 \%$ \\
Crude fibre & $10.55 \%$ \\
Carbohydrate & $70.27 \%$ \\
Crude protein & $9.53 \%$
\end{tabular}

Percentage value of proximate analysis revealed carbohydrate as the highest percentage followed by crud fibre and then crude protein and ash respectively. Fat is has the lowest percentage. 
Table 5: Analysis of some heavy metals in L. cupanioides

\begin{tabular}{ccc}
\hline Heavy metal & AAS value & Value in $\mathrm{mg} / \mathrm{kg}$ \\
\hline Cadmium $(\mathrm{Cd})$ & 0.009 & 0.09 \\
Chromium $(\mathrm{Cr})$ & 0.011 & 0.11 \\
Lead $(\mathrm{Pb})$ & 0.006 & 0.06 \\
Zinc $(\mathrm{Zn})$ & 2.046 & 20.06 \\
Cupper $(\mathrm{Cu})$ & 0.056 & 0.55 \\
Manganese $(\mathrm{Mn})$ & 0.044 & 0.43 \\
Nickel $(\mathrm{Ni})$ & 0.014 & 0.14
\end{tabular}

In table 5; $\mathrm{Zn}$ was observed as the highest metal, followed by $\mathrm{Cu}$ and $\mathrm{Mn}$ respectively. The lowest was $\mathrm{Cd}$. All metals were present at permissible level.

\section{Discussion}

Medicinal plants have been used for management of many health challenges as they are natural sources of numerous bioactive compounds (secondary metabolites) possessing vital bioactivities. These metabolites are chemical constituents and have been used in traditional folks as drugs [10]. Some of the advantages for medicinal plants patronage include cost effectiveness, broad spectrum activities, little or no side effects, curative and preventive activities [10-12]. In this study L. cupanioides was evaluated for its subchronic toxicity in mice.

Body weight is a pertinent criteria in evaluating toxic effects of treatments, drugs or toxic substances [13]. Variation in weights can be one of the first critical evidence of toxicity [14]. Evaluation of growth in animals utilizing weight index is a commonplace in toxicological investigations as it assist in interpreting compound-related effects [15]. In this investigation, weight of mice assessed weekly for 49 days did not show any significant difference, implying that the extract does not seem to possess any threat to the physiognomy of the mice.The bone marrow $\mathrm{Mn}$ test is a popular in vivo assay for investigating genetical aberrations in animals like mice and rats. A $\mathrm{Mn}$ is round and has diameter of about $1 / 20$ th to $1 / 5$ th RBC. Bone marrow PCE to NCE ratio in prepared slides, is important in evaluating any aberrations in hematopoiesis consequent upon animal's exposure to treatments [16]. The choice of MN assay amongst array of genetic batteries was to investigate the potential risk for chromosome damage in bone marrow of mice exposed to different concentrations of L. cupanioides. MN has been described as a biomarker for chromosomal damage. In young and new erythrocytes. MN emerge mainly from fragments of chromosomes not incorporated within the daughter nuclei during mitosis of the erythropoietic blast cells [17]. The extract insignificant effect as observed against control in the PCE/ ( $\mathrm{PCE}+\mathrm{NCE})$ suggest that it is not cytotoxic [18]. Significant increase in the frequencies of micronucleated PCE and NCE formation in mice confirms clastogenicity of test substance and that increased in frequency of NCE in exposed mice indicated that test substance constituents increased the rate of ageing of PCE, thereby decreasing their normal life span and increasing their risk of genotoxicity $[7,19]$. Since this study did not show any significant treatment related increase in the frequencies of MN PCEs and NCE it therefore predicts that L. cupanioides does not have clastogenic effects and does not increase the risk of genotoxicity. Various nuclear abnormalities scored to complement MN frequency in the toxicity assessment did not show significant increase against control, indicating absence of cytotoxic and genotoxic agents, as the simultaneous formation of nuclear abnormalities (NAs) and MN in erythrocytes treated with test substance is considered a better indicator of cytotoxicity and genotoxicity monitoring of the clastogenic effects of treatments [20]. However significant increase in binucleated erythrocytes formation suggests that constituent of test substance inhibited cytokinesis of the dividing cell, which is in line with Ozkan et al., [21]. There was no reported increase in the frequency of observed nuclear bud in the erythrocytes; as increase may suggest clastogenicity and aneugenicity to dividing cells in the bone marrow [22].

Heavy metals can be absorbed from soil contaminated with high level of it due to their non-biodegradability resulting in its bioavailability to humans. Heavy metals in high proportion portends high toxic risk to health. $\mathrm{Pb}, \mathrm{Cd}, \mathrm{Cr}, \mathrm{Cu}, \mathrm{Ni}$, and $\mathrm{Zn}$ possess permissible limit of $10,1,1.5,10,1.5$ and $50 \mathrm{ppm}$ respectively [8]. Physico-chemical investigation on L. cupanioides revealed the presence of $\mathrm{Cu}, \mathrm{Cr}, \mathrm{Mn}, \mathrm{Ni}$, and $\mathrm{Cd}$ at permissible level, which implies that the extract may elicit myriads of health benefits to justify its traditional use. The extract may play an important role in a number of physiologic processes due to the presence of Manganese (Mn), which can also serve as activator of other enzymes [23]. Manganese is the preferred cofactor of enzymes called glycosyltransferases; these enzymes are required for the synthesis of proteoglycans that are needed for the formation of healthy cartilage and bone [24]. Manganese is required for the activation of prolidase, an enzyme that functions to provide the amino acid, proline, for collagen formation in human skin cells [25]. Availability of copper in the extract can also make L. cupanioides elicit many physiologic activities as copper is a critical functional component of several essential enzymes known as cu proenzymes [26]. The plant might also help in enhancing sensitivity of tissues to insulin and facilitating transportation of glucose into cells, due to the presence of chromium in its extract. Chromium has been proposed to be the cofactor for an oligopep- 
tide called chromodulin which is a factor that may be able to potentiate the action of insulin [27]. Zinc, a nutritionally essential mineral needed for catalytic, structural, and regulatory functions in the body [28] also observed in L. cupanioides in conjuction with other element may be responsible for some of its medicinal values and managing of some health malaise [29]. Nickel also plays some role in body functions including enzyme functions [30]. Copper is a co-factor for metalloproteins and play a major role in several metabolic pathways [31]. Lead was found beyond permissible limit which may indicate that the plant may possess some toxicity [32].

\section{Conclusion}

L. cupanioides did not cause any genotoxic effect in the bone marrow cells within the exposure period and doses examined. Heavy metals were observed at permissible level, confirming its health potentials. However, further assessment and evaluation on the medicinal uses and safety especially when administered at higher doses and a longer period of time should be executed.

\section{Acknowledgment}

I appreciate Mr. A. E. Adeshola for proper care of the mice during the period of treatment in the animal house of the Department of Cell Biology and Genetics, University of Lagos.

\section{Authors' contribution}

The manuscript was written, and approved in collaboration with all authors.

\section{Conflict of interests}

All authors declare that there is no conflict of interest.

\section{References}

1. Abbasi A, Khana M, Mushtaq A, Muhammad Z, Sarwat J., Shahzia S. Ethnopharmacological application of medicinal plants to cure skin diseases and in folk cosmetics among the tribal communities of North-West Frontier Province. Ethnopharmacol. 2010; 128: 322-335.

2. World Health Organisation (WHO). Traditional Medicine Strategy. Geneva 2014; 10(6): 15-20.

3. Nafiu M, Abdulsalam T, Jimoh R, Kazeem M. Ameliorative Effect of Lecaniodiscus cupanioides (Sapindaceae) Aqueous Root Extract in Loperamide-Induced Constipated Rats. Trop J Pharmac Res. 2015; 14 (6): 1057-1062.

4. Olaide N, Ajiboye T. Aqueous root extract of Lecaniodiscus cupanioides restores the alterations in testicular parameters of sexually impaired male rats. Asian Pacific J Reprod. 2012; 1(2): 120-124.

5. Yemitan O, Adeyemi O. CNS depressant activity of Lecaniodiscus cupanioides, Fitoterapia. 2005; 76 (5):412-418.

6. Adeyemi $\mathrm{O}$, Yemitan $\mathrm{O}$, Adeogun $\mathrm{O}$. Analgesic activity of the aqueous root extract of Lecaniodiscus cupanioides. West African J Pharmacol Drug Res. 2004; 20 (1-2): 10-14.

7. Alimba $C$ and Bakare A. In vivo micronucleus test in the assessment of cytogenotoxicity of landill leachates in three animal models from various ecological habitats. Ecotoxicol. 2016; 25: 310-319.

8. Ayaz M, Junaid M, Subhan F, Ullah F, Sadiq A, Ahmad S. Imran M, Kamal Z, Hussain S and Shah, S. Heavy metals analysis, phytochemical, phytotoxic and anthelmintic investigations of crude methanolic extract, subsequent fractions and crude saponins from Polygonum hydropiper L. BMC Complementary and Alternative Med. 2014; 14:465 -474.
9. AOAC. Minerals: In Official Methods of analysis, Washington, DC: Association of Official Analytical Chemists. 2010; 16(3): 99-103.

10. Chin $\mathrm{Y}$, Balunas $\mathrm{M}$, Chai $\mathrm{H}$ and Kinghorn A. Drug discovery from natural sources. AAPS J 2006; 8: 239-53.

11. Pcerangeli G, Vital G, Rivera W. Antimicrobial activity and cytotoxicity of Chromolaenaodorata (L. F.) king and rabinson and Uncariaperrottetii (A. Rich) Merr extracts. J Med Plants Res. 2009; 3(7):511-518.

12. Sermakkani M, Thangapandian V. GC-MS analysis of Cassia itallica leaf methanol extract. Asian J Pharmac Clin Res. 2012; 5(2):90-94.

13. Ferreira S, Guimarães A, Ferraria F, Carneiro C, Nogueira de Paiva N. and Guimarães D. Assessment of acute toxicity of the ethanolic extract of Lychnophora pinaster (Brazilian arnica) Revista Brasilia de Farmacognosia. 2014; 24: 553560.

14. Ajayi A, Ayodele E, Ben-Azu B, Aderibigbe A, Umukoro $S$. Evaluation of neurotoxicity and hepatotoxicity effects of acute and sub-acute oral administration of unripe ackee (Blighia sapida) fruit extract. Toxicol Reports. 2009; 6: 656-665.

15. Murbach T, Glavits R, Hirka G, Endres J, Clewell A, Szakonyine I. A 28-day oral toxicology study of an aqueous extract of Polypodium leucotomos (Fernblock $\mathbb{R})$, Toxicol Reports. 2017; 4: 494-501.

16. Shokrzadeh M, Chabra A, Naghshvar F, Ahmadi A. The Mitigating Effect of Citrullus colocynthis (L.) Fruit Extract against Genotoxicity Induced by Cyclophosphamide in Mice Bone Marrow Cells. Scient World J. 2013(4): 980480.

17. Habibi E, Shokrzadeh M, Ahmadi A, Chabra A, Naghshvar F, Keshavarz-Maleki R. Genoprotective effects of Origanum vulgare ethanolic extract against cyclophosphamide-induced genotoxicity in mouse bone marrow cells. Pharmac Biol. 2015; 53(1): 92-97.

18. Krishna G, Hayashi M. In vivo rodent micronucleus assay: protocol, conduct and data interpretation. Mutation Research/Funndamental and Molecular Mechanisms of Mutagenesis. 2000; 455(1-2): 155-166.

19. Alabi O, Osifo-Whiskey E, Yadi P, Lawal M, Bakare A. Tobacco industry wastewater-induced genotoxicity in mice using the bone marrow micronucleus and sperm morphology assays. Cytologia. 2014; 79(2): 215-225.

20. Carrasco K, Tilbury K, Mayers M. Assessment of the piscine micronuclei test as an in situ biological indiator of chemical contaminants effects. Canadian J Fisheries Aquatic Sci. 1990; 47(11): 2123-2136.

21. Ozkan F, Gunduz S, Berkoz M, Hunt A. Induction of micronuclei and other nuclear abnormalities in peripheral erythrocytes of Nile tilapia, Oreochromis niloticus, following exposure to sub-lethal cadmium doses. Turkish J Zool. 2011; 35: 585-592.

22. Alimba C, Aladeyelu A, Nwabisi I, Bakare A. Micronucleus cytome assay in the differential assessment of cytotoxicity and genotoxicity of cadmium and lead in Ametophrynus regularis. EXCLI J. 2018; 17; 89.

23. World Health Organization. Vitamin and mineral requirements in human nutrition (2e), 2004 http://www.who.int/ vmnis/en/.

24. Keen C, Zidenberg-Cherr S. Manganese toxicity in humans and experimental animals. Manganese in Health Dis. 1994; 1(1):193-205.

25. Muszy凶ska A, Pałka J, Gorodkiewicz E. The mechanism of daunorubicin-induced inhibition of prolidase activity in human skin fibroblasts and its implication to impaired collagen 
biosynthesis. Experim Toxicol Pathol. 2000; 52(2):149-155.

26. Prohaska J. Impact of copper limitation on expression and function of multicopper oxidases (ferroxidases). Advances in Nutrition. 2011; 2(2): 89-95.

27. Vincent J. Elucidating a biological role for chromium at a molecular level. Accounts Chem Res. 2000; 33(7):503510.

28. King J, Cousins R. Zinc. In: Ross AC, Caballero B, Cousins RJ, Tucker KL, Ziegler T.R.,eds. Modern Nutrition in Health and Disease. 11th ed. Baltimore: Lippincott Williams \& Wilkins. 2014; 2510.

29. Oladimeji-Salami J, Akindele A, Adeyemi O. Effects of ethanolic dried leaf extract of Lecaniodiscus cupanioides on antioxidant enzymes and biochemical parameters in rats. J Ethnopharmacol. 2014; 155(3): 1603-1608.

30. Sobukola O, Adeniran O, Odedairo A, Kajihausa O. Heavy metal levels of some fruits and leafy vegetables from selected markets in Lagos, Nigeria. African J Food Sci. 2010; 4(6): 389-393.

31. Gajalakshmi V Iswarya, Ashwini R, Divya G, Mythili S, Sathiavelu A. Evaluation of heavy metals in medicinal plants growing in Vellore Districts. European Journal of Experim Biol. 2012; 2 (5):1457-1461.

32. Lakshmi P, Vijayaraghavan R. Insight into the mechanism of antibacterial activity of $\mathrm{ZnO}$ : surface defects mediated reactive oxygen species even in the dark. Langmuir. 2015; 31(33): 9155-9162

33. Pandey M, Abidi A, Singh S, Singh R. Nutritional Evaluation of Leafy Vegetable Paratha. J Human Ecol 2006; 19 (2): 155156.

34. Emebu P, Anyika J. Proximate and mineral composition of Kale (Brassica oleracea) grown in Delta State, Nigeria. Pakistan Journal of Nutrition 2011; 10(2): 190-194.

35. Ejelonu B, Lasisi A, Olaremu A, Ejelonu O. The chemical constituents of calabash (Crescentia cujete). African J Biotechnol 2011; 10(84): 19631-19636.

36. Achi N, Chimaraoke Onyeabo C, Ekeleme-Egedigwe C, Onyeanula J. Phytochemical, Proximate Analysis, Vitamin and Mineral Composition of Aqueous Extract of Ficus capensis leaves in South Eastern Nigeria. J Appl Pharmac Sci. 2017; 7 (03); 117-122.

37. Ejoh R, Tchouanguep M, Fokou E. Nutrient compostion of the leaves and flower of Colocassia esculenta and the fruits of Solanum melongena. Plant Food Human Nutr. 1996; 49: 107-112.

38. Abolaji O, Adebayo A, Odesanmi O. Nutritional qualities of three medicinal plant parts (Xylopia aethiopica, Blighia sapida and Parinari polyandra) commonly used by pregnant women in the Western Part of Nigeria. Pakistan J Nutr.2007; 6 (6): 665-668.

39. Olowokudejo J. Conservation and Sustainable Uses of Medicinal Plants in Nigeria. A Textbook of Medicinal Plants from Nigeria. 2008; 159. 